open 2 Access

\title{
Umoljani Village on Bjelašnica: Life in the Way of Sustainability
}

\author{
Ahmet Hadrović* \\ Faculty of Architecture, University of Sarajevo, Sarajevo, Bosnia and Hercegovina
}

Citation: Hadrović A. Umoljani Village on Bjelašnica: Life in the Way of Sustainabih. UnE J Archil Des. 2020 May 11; 10047:19. http://dx.doi.org/10.3889/seejad.2020.10047

Key words: Bjelasnica; Water; Pastures; Traditional architecture; Sustainability

Correspondence: Prof. Dr. Ahmet Hadrović, Faculty of Hercegovina. E-mail: ahmeth@af.unsa.ba

Received: 06-Apr-2020; Revised: 20-Apr-2020; Accepted: lished: 11-May-2020

Copyright: @ 2020 Ahmet Hadrović. This is an open-access article distributed under the terms of the Creative Commons distribution, and reproduction in any medium, provided the original author and source are credited.

Competing Interests: The author have declared that no competing interests exist.

\section{Abstract}

Bjelasnica Mountain occupies a central place in the geographical area of Bosnia and Herzegovina. Due to this fact, its altitude (2067 m), it is the border between Bosnia, on the one hand, and Herzegovina, on the other and the border between the changed mediterranean and continental climates (while Bjelasnica itself has a mountainous to alpine climate). Due to these natural inputs, Bjelasnica is a "rain and snow catcher", and because of its geological structure (mostly limestone), it is also the largest reservoir of water in $\mathrm{B} \& \mathrm{H}$. That is why Bjelasnica is considered to be the "mother of $\mathrm{B} \& \mathrm{H}^{4}$, since at its base there are springs of two of the most important rivers in B\&H (Bosnia and Neretva), and on its own (plateau of Bjelasnica) a large number of springs, watercourses, permanent lakes and bars. Natural conditions have been a magnet for inhabiting the Bjelasnica plateau, from prehistory to the present. Due to its specific natural values, in a combination of favorable social environment, Bjelasnica (with Jahorina, Trebevic and the city of Sarajevo itself) hosted the 14th Winter Olympic Games (1984) and subsequently hosted several FIS-races.

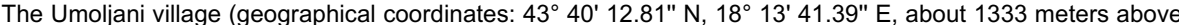
sea level) is located on the southern slope of Bjelasnica mountain, in a gentle plain. The village belongs to the municipality of Trnovo (it is about $16.3 \mathrm{~km}$ away from Trnovo by air, $23 \mathrm{~km}$ from Sarajevo). Due to the abundance of natural resources (water, arable land, meadows, pastures, forests), the area of the Umoljani is constantly inhabited, from prehistory to the present. The presence of people in this area is evidenced by many cultural and historical monuments: antique hillforts, medieval necropolis of tombstones (stećci), remains of a medieval church, necropolis from the ottoman conquest and one of the oldest mosques in Bosnia and Herzegovina. Until the war in Bosnia and Herzegovina (1991-1995), the village lived in a more or less traditional way, within its traditional physical structure. During the war the village was flooded and its population was exiled. After the war, the village was quickly rebuilt, but in the changed socio-economic circumstances, and with architectural structures that in all respects reflect modern life. It is of the importance that the katun settlement (Gradina) above the village with traditional architectural objects is preserved, as a picture of the former Umoljani village.

The Umoljani village is an exemplary study of the metamorphosis of settlements (driven by the changing social environment), in the rich natural environment where they continue to live, partly in the traditional way, and partly in the modern way, that is, in the way of sustainability.

\section{Introduction}

The Umoljani village (geographic coordinates: $43^{\circ} 40^{\prime} 12.81 " \mathrm{~N}, 18^{\circ} 13^{\prime} 41.39^{\prime \prime} \mathrm{E}$, about 1333 meters above sea level) is located on the southern slope of Bjelasnica mountain, in the gentle plateau (Figure 1) [1]. The village belongs to the municipality of Trnovo (about $16.3 \mathrm{~km}$ by air line). According to the 2013 census, there were 43 inhabitants, which is less than the 1991 census (92), the 1981 census (245) and the 1971 census $(415)$.
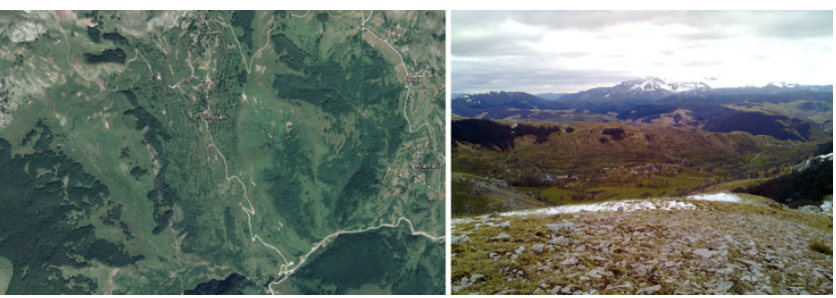

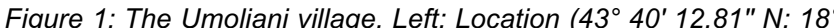
13' 41.39" E; Elevation: 1333 m). Source: Google Earth. Accessed: 01/29/2020. Right: Gradina view (Treskavica mountain in the background) 
According the theory of space developed by the Author in 1987, the Umoljani village will be considered in this paper as a system, that is, an architecturally defined space (ADP) through consideration of its four basic elements: environment, man, boundaries and perspectives [2], (Figure 2). Simultaneous representation of these elements will determine their mutual cause-effect relationship and will not leave out anything that is important for the formation of the image of this space.

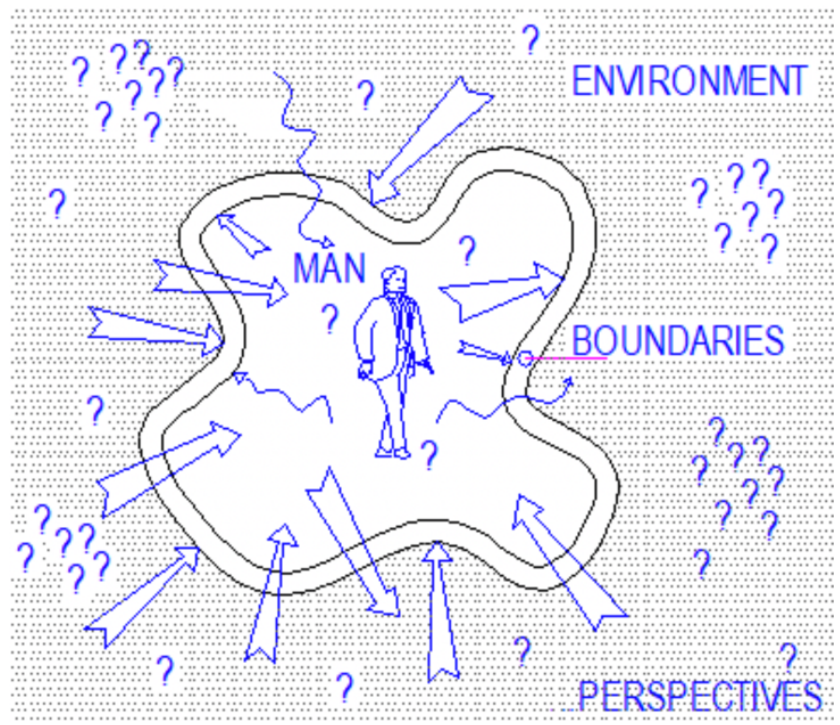

Figure 2: Architectural Defined Space (ADP)

\section{Environment}

By the term "environment" we mean every possibility in a space in which a person can achieve his existence [3].

\section{The Natural Environment}

By the natural environment we mean all those data provided by nature, on which man (mostly) has not exercised his influence: geographical location, geomorphology, water flows and aquatic reservoirs, wildlife, available soil, climate ...

The Bjelasnica plateau is a vast geographical area in the central part of Bosnia and Herzegovina, with the summit of the Bjelasnica mountain as a central point, framed by the Igman, Ivan-Planina, Visocica and Treskavica mountains. The plateau is about $25 \mathrm{~km}$ southwest of Sarajevo. This plateau (along with the Igman mountain that is part of it) extends about $30 \mathrm{~km}$ in a northeast-southwest direction, perpendicular to the Dinaric massif and a width of about $10-20 \mathrm{~km}$. The northernmost part of Bjelasnica (also its highest ridge) extends from east to west for about $12 \mathrm{~km}$. At the far eastern edge of this ridge is the highest corner of Bjelasnica with a meteorological station (observatory). The boundaries of this plateau are the flow of the Zujevina river and Igman mountain in the north, the Hojta ridge and Treskavica mountain in the southeast, the $25 \mathrm{~km}$ long Rakitnica river canyon (which divides the Bjelasnica plateau and Visocica mountain) to the south, the Neretva river valley (which separates the Bjelašnica plateau and Prenj mountain) to the southwest, and the Ivan-mountain saddle (which connects the Bjelasnica plateau with the Bitovnja mountain) to the west. Bjelasnica is named after the white snow blanket („kapa“) that stays there for most of the year, from november to may (sometimes in the summer). The highest peak of Bjelasnica $(2067 \mathrm{~m})$ is also called the Observatory, according to the meteorological station there. Bjelasnica is the Olympic mountain, today a favorite excursion site for Sarajevo that offers great opportunities for skiing (on Olympic trails), walking and hiking, mountain biking, rafting (on the Rakitnica river), paragliding in the air and in the snow ...

Bjelasnica plateau is rich in various relief forms. From a geological point of view, Bjelasnica is part of the Dinaric Alps, composed of secondary and tertiary sedimentary rocks, mainly limestone and dolomite. The largest part of Bjelasnica is built of middle and upper Triassic limestones and dolomites. There are differences in the geological composition of its individual parts. The rocks on the eastern part of the mountain, east of Umoljani (the valley of the Rakitnica river around the Šabići village and Rakitnica) are formed into clayey, ie waterproof marls, sandstones.

The climate of Bjelasnica is of a transitional character, between mediterranean and continental influences, with dominant characteristics of mountain and alpine climate. In the greater Bjelasnica area below 1500 meters above sea level, there is a mountain climate (type Dfb, according to the Köppen classification of climate, humid boreal climate with warm summer). This type of climate is characterized by large annual amplitudes: mean temperatures of the warmest month $\leq 22{ }^{\circ} \mathrm{C}, 3$ to 4 and even 5 months temperatures are lower than $0{ }^{\circ} \mathrm{C}$, coniferous forests and steppes develop in arid regions, and deciduous forests in wetter ones. In areas with an altitude of more than 1500 meters above sea level, a mountain climate (type Dfc according to the Köppen classification, humid boreal climate with fresh summer) is represented. This type of climate is characterized by long, very cold winters and short fresh summers - for only 1 to 4 months the average temperature is $\geq 10{ }^{\circ} \mathrm{C}$. Due to its geographical location and altitude, Bjelasnica represents the limit of influence of two large climatic units - mediterranean and continental. Thus, the Bjelasnica clashes with Adriatic and continental air masses, which results in frequent and rapid changes in weather conditions, frequent and strong winds and heavy rainfall, 
relatively early occurrence of the first snow and frost (mid-september), as well as long retention of heavy snow cover in higher areas (until the second half of may). There is plenty of precipitation every season. The average annual rainfall in the mountainous area exceeds $1200 \mathrm{~mm}$, and it is mostly snowfall that persists for a long time. The mountain is generally known for strong and frequent winds, and at the top of Bjelasnica sometimes in the winter months they reach hurricane force and speed of over $100 \mathrm{~km} / \mathrm{h}$.

Resources are natural wealth that are more or less directly used by a person to satisfy a wide range of needs. Given their abundance, we distinguish between renewable and non-renewable resources. Renewable resources are: Solar radiation, water, forests and living things in general. Non-renewable resources include oil, gas, coal and minerals. In our considerations we will treat water, forest (as a resource created more or less without human influence), soil (as a "derived“ natural resource, without or with human activity) in the emergent forms of forest pastures, cultivated meadows and fields, orchards as renewable resources (as human cultivated and especially purposeful trees, or plant biomass). Of non-renewable resources, stone is the most important, as building material, above all.

The Rakitnica river springs at the western end of Treskavica near the Rakovica village, at an altitude of between 1300 and 1500 metres above sea level and flows into the Neretva on the Bjelasnica-VisočicaPrenj mountain tributary, as its right tributary, not far from Boračko jezero (Boracko Lake), at an altitude of 324 metres above sea level. This typical mountain river cuts deep between Bjelašnica on the right and Visočica on the left, forming a canyon, a morphological phenomenon, and an idyllic wonder of wild nature, with a series of rapids, waterfalls, waterfalls, and peaceful pools (Figure 3 ).

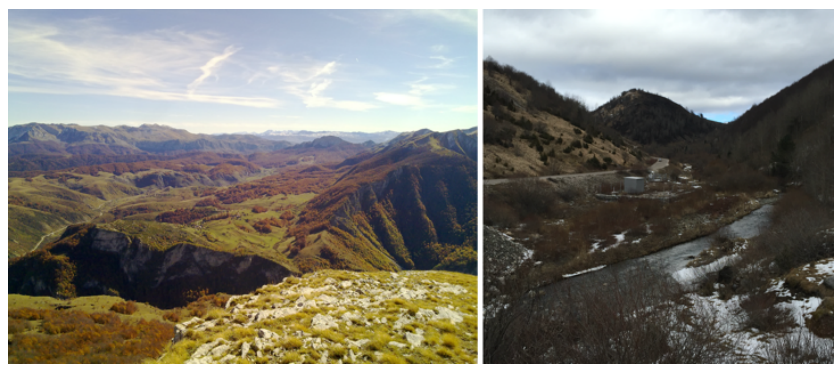

Figure 3: View from the Obalj to the Rakotnica Canyon (left). Wastewater collector along the Rakitnica River (below the village of Umoljani, directly in front of its canyon)

Rakitnica canyon is the longest and deepest in Bosnia and Herzegovina. It is over $20 \mathrm{~km}$ long and the depth ranges between 800 and $1000 \mathrm{~m}$. The beginning of the Rakitnica Canyon is at an altitude of $1120 \mathrm{~m}$. It is a stream of $4-5 \mathrm{~km}$ with a fall of about $300 \mathrm{~m}$ and numerous waterfalls and waterfalls. Until the 1992-1995 war, Rakitnica was the site of a large number of watermills, and today it is a natural attraction for many visitors.

The Dugo polje („Long field“) is a nearly $4 \mathrm{~km}$ long valley between the slopes and hills of Krvavec, to the west and northwest and Obalj to the southeast (Figure 4). It extends in a southwest-northeast direction, with a slight bend to the east in one-third of its length (the northern part). At its extreme southwest, it passes into a vertically laid cove of Mrkovalje, which continues in a southeast direction, parallel to the ridge of Lovnica, all the way to Gornji Lukomir, which rises above the Rakitnica canyon.

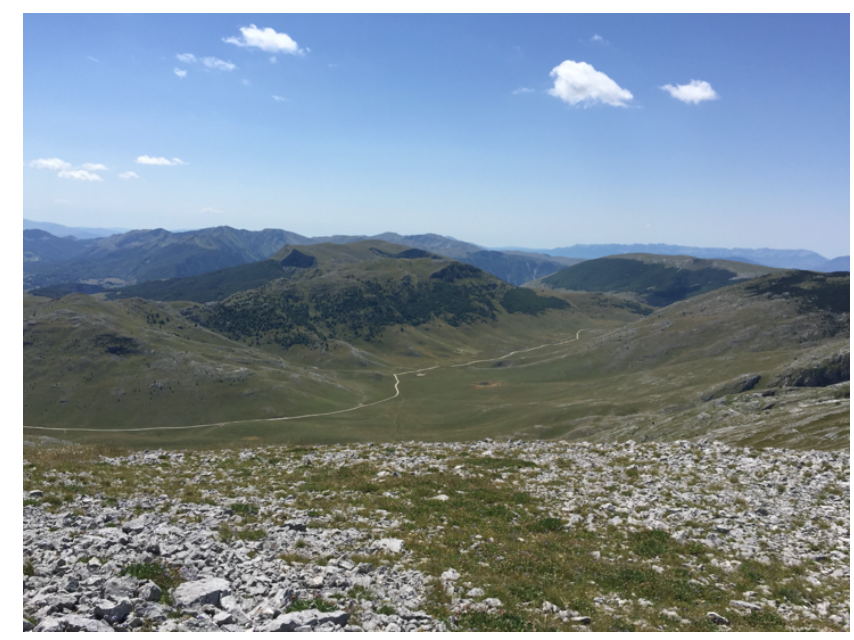

Figure 4: Dugo polje („Long field“). View from the peaks of Bjelasnica

\section{Social Environment}

The social environment represents everything that man has created and what sets him apart from the world of other living beings. It encompasses both physical structures (various material, more or less ordered products of their activity), as well as the intangible world that we recognize by intellect (science, philosophy, religion, law, morals) through an ordered system of abstract symbols (letter, signs). According to research to date, part of today's villages on the Bjelašnica plateau can be traced back to the 14th century, when they were still used for the summer grazing of Herzegovina's nomads. However, there was life on the mountain even earlier, as evidenced by numerous necropolises of tombstones (stećci), as well as archeological findings from earlier historical periods (Neolithic, Illyrian times, such as Gradina, fortifications near the Umoljani village), (Figure 5).

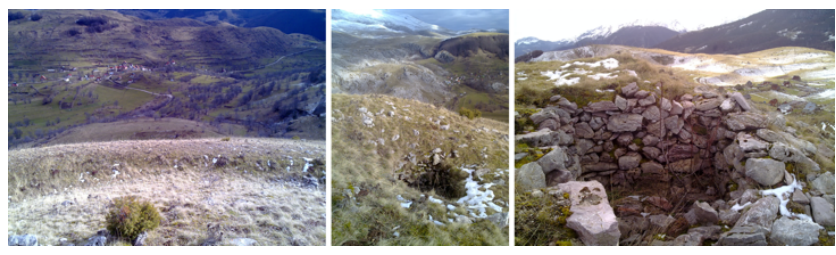

Figure 5: The remains of Gradina above Umoljan 
There is also the site of Crkvine, located not far from the Rakitnica river on a hill above the medieval cemetery. For a long time, there was a conviction that the area of Bjelasnica villages was an area of worship, where this teaching and world view persisted for the longest time.

The population of the celebrated Illyrian novels dealt predominantly with livestock and „kiridžija" affairs. They contacted the Dalmatian cities that traded with the Slavic hinterland. The goods were transported by caravans - horses, mules, and donkeys. Among the villages of Bjelasnica are the Donji and Gornji Kramari, whose name (probably) comes from the Vlach caravan elders called kramari. The peaks of Velika and Mala Vlahinja testify to this claim.

Several necropolises on the plateau of Bjelasnica, including the one in the Umoljani village, dating from the 14th and 15th centuries, testify to the existence and teaching of the "Bosnian Church“, that is, people who considered themselves "true christians" - bogumils. The Ottoman census of Herzegovina (dating from 1477, fourteen years after the fall of Bosnia under the Ottoman Empire) mentions the Tušila Bjelasnica village, belonging to the Zagorje Grgura vojvode (Gregory of the Duke), (There is one house on this timar that is occupied by Radovan son of Miroslav. The income mentions wheat, oats, and some vegetables with a very meager income of 214 acres, while the village of Drezica, for example, has income of 1992 acres).

The necropolis of the tombstones in the Umoljani village (at the Dolovi site) is part of a wider unit, the National monument, which includes 53 tombstones, 11 old nišan-tombstones and the remains of an old church located at 6 locations near the Umoljani village (1. Necropolis of 47 tombstones (stećci) at the Dolovi site (6 slabs, 32 chest, 5 tall chest and 4 gabled, 12 of which are decorated); 2. Eleven old nišan-tombstones, spread over two hills above the Dolovi site; 3 . Outline of the place where the church was located in Crkvina; 4. A secluded ornamented tombstone (stećak) on a hill about $500 \mathrm{~m}$ west of the Dolovi site; and 5. Necropolis with 5 stećak-tombstones completely sunken (on a hill about $200 \mathrm{~m}$ west of the secluded stećak).

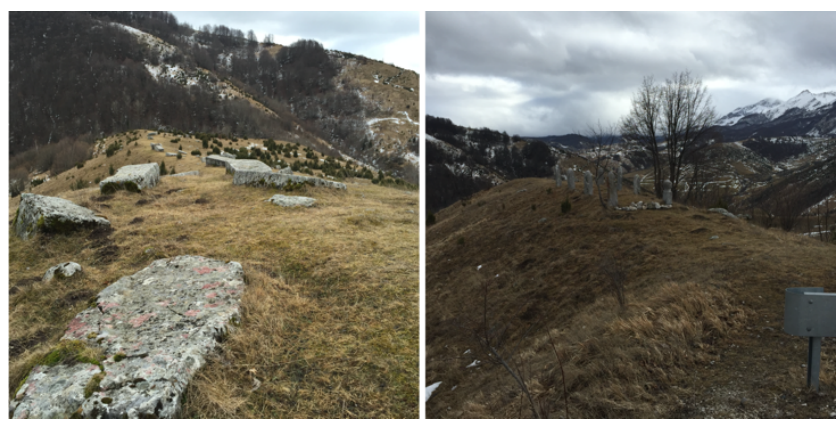

Figure 6: Necropolis of tombstones (stećci) at Dolovi near Umoljan (left) and four cemeteries (Shehids of Mehmed II Fatih's army, right)
The necropolis of stećak tombstones in the Umoljani village is on the list of 30 medieval necropolis of stećak- tombstones that were declared a UNESCO World Heritage Site in 2016. The necropolis is also a national monument of Bosnia and Herzegovina (Figure 6).

Umoljani Mosque is a national monument of Bosnia and Herzegovina. There are no written marks on the construction of this mosque (vakufname or any other written document). It is believed that the first construction of the mosque (since 200 years ago) at this site was made of wood, and that the present construction was built at the beginning of the 20th century (Figure 7). The mosque in Umoljani is known, among other things, for the fact that the famous Sarajevo Haggadah was preserved there during World War II. This is the only facility on the part of the Bjelasnica plateau belonging to the municipality of Trnovo that remained unburnt during the 1992-1995 war.

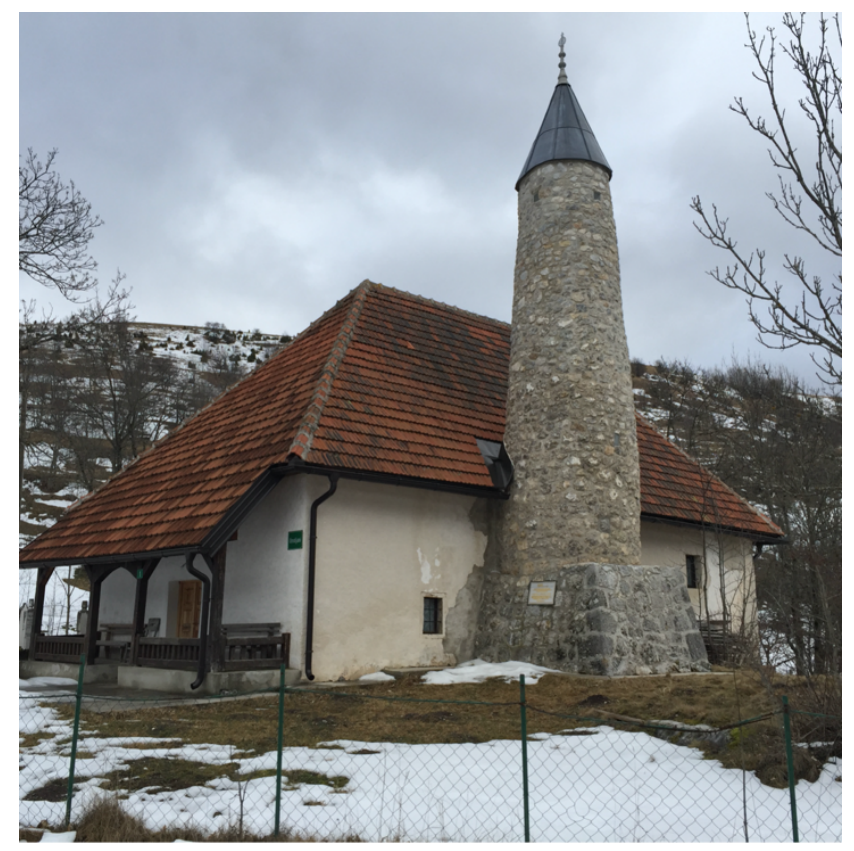

Figure 7: Umoljani Mosque

The strategic importance of Bjelasnica was already known in the SFRY when a large radar station on one of the peaks of the Vlahinja ridge was built on it for the needs of the JNA, and a communications center and a tower were built adjacent to the meteorological station at the top of the mountain. Bjelasnica also played a strategic role during the war in Bosnia and Herzegovina, during the siege of Sarajevo (1992-1995). During this period, the area of Bjelasnica and Igman, between Konjic and Sarajevo Airport (controlled by UN forces) was controlled by the forces of the Army of Bosnia and Herzegovina.

Due to its exceptional beauty and natural resources and rich cultural and historical heritage and its people (preserved traditional costumes and 
hospitality), the Bjelasnica plateau attracted many scientists, artists, nature lovers (Inspired by the beauties of the Bjelasnica plateau, many documentaries and feature films were filmed there, including the documentary Blessing on Bjelasnica, which was made for German television WDR in the 1980s and relates to the Umoljani village).

Socio-economic relations, on the one hand, show the degree of development of productive forces and the degree of social upgrading, on the other, reflect the relationship of production forces and production relations. In this way, socio-economic relations become an essential mirror of the whole society.

Despite the great social changes, the life of the people in the Umoljani village (and on the Bjelasnica plateau as a whole) remained within the traditional framework until the war (1992-1995) when great changes occurred here as well. During the war (1992-1995), the inhabitants of many villages (among them the inhabitants of the village of Umoljani) on the Bjelasnica plateau were expelled and their villages burned down. In exile (in Sarajevo, Konjic and around the world), a new generation of people was born, who started a new life there, not at all similar to the tradition of their ancestors. In new environments, their parents found new jobs and started new households. With the end of the war, many people returned to the Bjelasnica plateau, made their homes, less often on the foundations of earlier houses that were devastated, mostly houses in new locations in the village and patterns of construction of houses anywhere in Bosnia and Herzegovina. For some people, building new homes was to maintain a mental connection with their land and their ancestors (since they were still living in the city), while for others it was a rebuilding of an earlier life, with modern agricultural equipment and means of transport (tractors, multicultivators, motor mowers, vans, trucks ...). In new circumstances, some individuals spent only a period of summer living in Umoljani (growing sheep and cattle, cultivating land - mainly potato cultivation, keeping beekeepers) while spending the winter in the city (Visiting the Bjelasnica plateau, the author particularly liked to visit the Gradina katun settlement above Umoljani, where individuals made their new holiday homes on the grounds or next to the earlier houses of their ancestors. The wives of these men were selling mountain herbs and fruits along the footpaths along the footpaths, making "home made handicrafts", making tea and coffee for hikers).

The inhabitants of the Umoljani village are, by their ethnicity, Bosniaks. Islam, both as a religion and as an overall view of the world, has determined their psychological profile, value system and practical activity in all segments of life. In this sense, this area is recognizable not only in Bosnia and Herzegovina but beyond. The people of this region deeply believe that reverence for God is a basic prerequisite for order on Earth (and throughout the Cosmos).
Morality is a system of values that determines the relation of man to nature, the relation of manindividual to society, the relation of man to man, and the relation of man-individual to himself. Since this value system is not prescribed, it is not sanctioned in the same way. Nonetheless, he regulated these relations, often in a very rigorous manner, which, more often than not, had greater power than the law. Morality is temporally and spatially conditioned, which also gives it a mark of relativity (Figure 8).

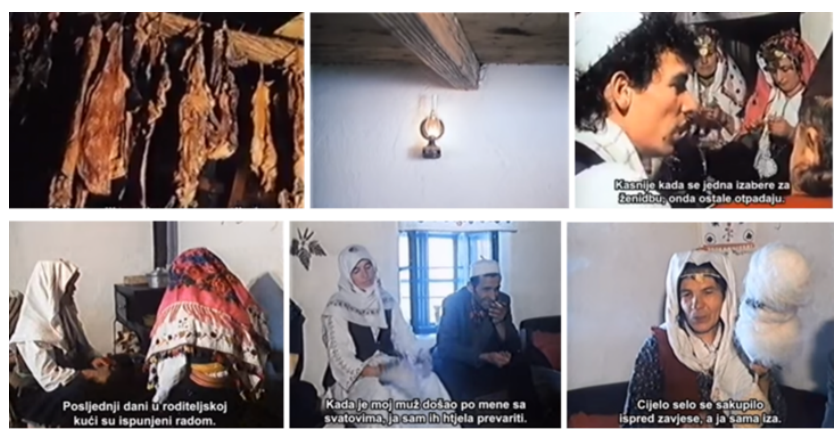

Figure 8: Atmosphere in a traditional house in Umoljani (Source: Bjelasnica Wedding Customs (1980s), https://www.facebook.com/BiHFolk/videos/555696468121483/)

Hence, moral values within one and the same social group or community are time-varying and influenced by the value systems of other communities that come to the community spontaneously, sometimes more or less intrusively. Collectivity and solidarity were the foundations upon which it operated and on which social communities developed in the Bjelasnica Plateau.

\section{Man}

Man is a huge question whose essence he himself tries to figure out within his own boundaries, within the boundaries of the Earth and the boundaries of the Universe. Together with the rest of the living world, he participates in the process of the circulation of matter and energy in nature, sharing with him the same destiny, birth and dying beyond his will. Being endowed with reason, will and feelings, he is the only one in the living world able to discover the given laws of the constitution of nature.

About the traditional way of life of the people on the Bjelasnica plateau, their customs, beliefs and morals, the documentary film Bridal customs on Bjelasnica was filmed for German television WDR in the 1980s (Figure 8). Within a household, there was a hierarchy of duties and responsibilities: at the top of the hierarchy was the husband/father who made the final decisions and whose orders had to be obeyed and obeyed; wife/mother was in charge of running a home economy and doing a number of jobs (servicing 
the barn with pets, weaving carpets and cotton cloth, making clothes, taking care of children, various field jobs ...); children assisted parents in various jobs and thus, in addition to their concrete impact, acquired knowledge of running the household; the grandparents had no strict household duties, and they did what they could and wanted.

Today's households are contemporary, similar to households in other parts of Bosnia and Herzegovina. People in the Umoljani village today, as a rule, have their houses in the city (Sarajevo, Hrasnica, Hadžići, Pazarić) where they live a city lifestyle, where they work and educate their children. Some of them go to the village in the summer to cultivate the land (mainly sowing potatoes, onions, carrots, parsley and less frequently peppers and tomatoes), collecting herbs and forest fruits and raising livestock. They have adequate means of transportation for transporting livestock, food, and other necessities. Some people have erected catering establishments (huts, houses, and lodging houses) and are involved in eco-tourism.

Of great importance in the life of the people of the Umoljani village (and the plateau of Bjelasnica) is the religious gathering of people, where apart from the religious act, it is extremely important to get to know each other individually, to communicate and socialize, both in mosques and outdoors. The weekly collective prayer is Juma-namaz on fridays, and the seasonal gathering is Mevlud (prayer and ceremony in honor of the birth of Prophet Muhammad, s.a.v.s.). In addition to religious gatherings, the Bjelašnica plateau is also known for holding summer teferiques (Figure 9), usually in late summer, whose significance is multidimensional in people's lives: relaxation and fun, trade, getting to know people (especially young people who are married)

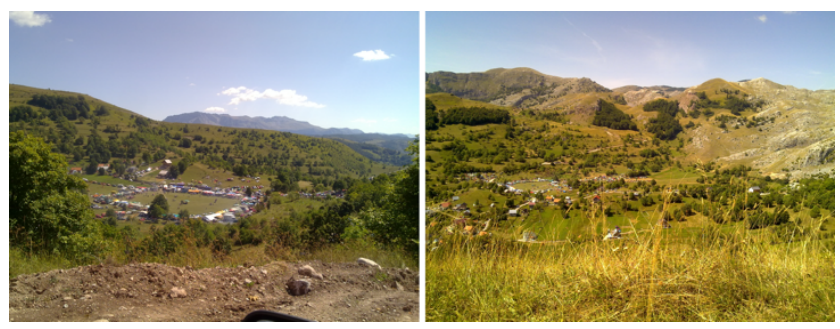

Figure 9: Folk fan (“Narodni teferič”, Umoljani village)

\section{Borders: Architecture as A Framework of Life}

Boundaries are those places of ADP (Architectural Defined Space) where, mainly in a materially exact way, the human needs, on the one hand, and the environment, on the other, are expressed. The boundaries are most often physically expressed, and often not mentally.

\section{Bjelasnica Plateau Level}

If you look at the plateau of Bjelasnica, on the plan and from the tops of the mountains at its edges (Figure 10), it can be seen that each village has its own area with which it acquires its identity of microsocial community. Each village has, within its range, basic resources that make it sustainable: a water source (with a public fountain), some villages and their own streams where water mills are arranged (with the Rakitnica river being a common resource for all villages), orchards, fields, more or less pastures, and some of the villages and their forest. The wide-open areas of the Bjelašnica mountains (and Visočice and Treskavica) are their common resource where large flocks of sheep are grazed during the summer.

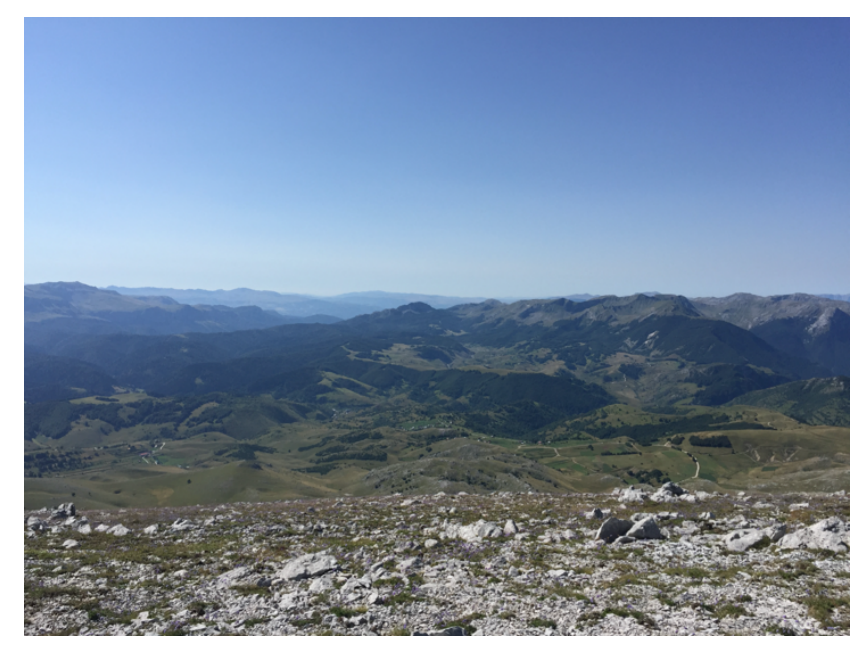

Figure 10: Bjelašnica plateau: view from the top of Bjelašnica towards Visočica

In these circumstances, close social relations are developed at the individual village level, within individual families, and at the village family level. Interconnection of two or more villages at the level of the Bjelasnica plateau, where each village from the perspective of the other "alien world" with its peculiarities, takes place in inter-familial relationships established by marriage, fans ("teferići"), villages, meetings in the central mosque (old mosque in Umoljani), trade, meetings in open pastures, mills on the central Rakitnica river. It seems that in this way a sufficiently rich social life is ensured that ensures the integrity of the individual and his social collectivities. The distance between the villages is large enough to allow people from one village to visit (especially earlier when walking or riding a horse) to experience an "event" rather than a routine.

\section{Level of the Umoljani village}

The main resources of the Umoljani village are fertile gardens adjacent to houses, arable land and meadows near the village, pastures around the village and beyond (Dugo polje and the southern 
slopes of Bjelasnica) and water.

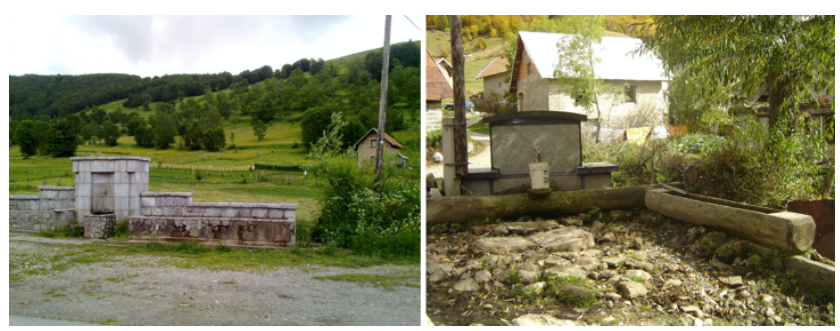

Figure 11: Central village fountain in Umoljani (left) and commemorative fountain of the Bosnian shehids (1992-1995) with cattle feed in Gornji Umoljani

Except in the village itself, springs and public fountains with livestock feeders are found in the pastures themselves (Figures 11, 12, and 13).
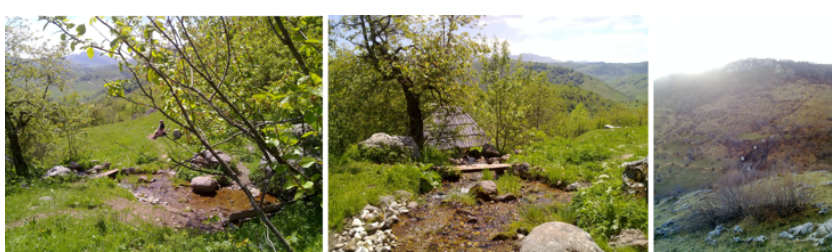

Figure 12: Source-stream-mill (Sedrenik) in the Umoljani village

Particularly significant is the source and stream „Sedrenik“ near the village, where nine water mills were erected, which indicates the great needs of the village and its economic strength (Figure 12, right).

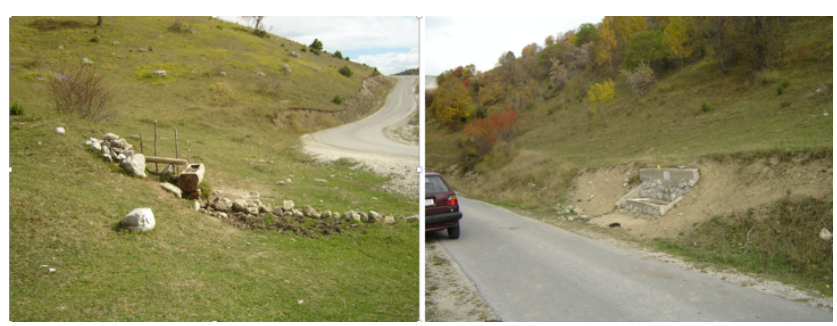

Figure 13: Hair-fountain along the Šabici-Umoljani road (locality Dolovi)

Immediately above the village is the Katun settlement of Gradina (Figures 14, 15, and 16), and above it, on Pošijak hill, remains of a prehistoric gradinekoko that testify to the age of settlement of this area (Figure 5) [4].
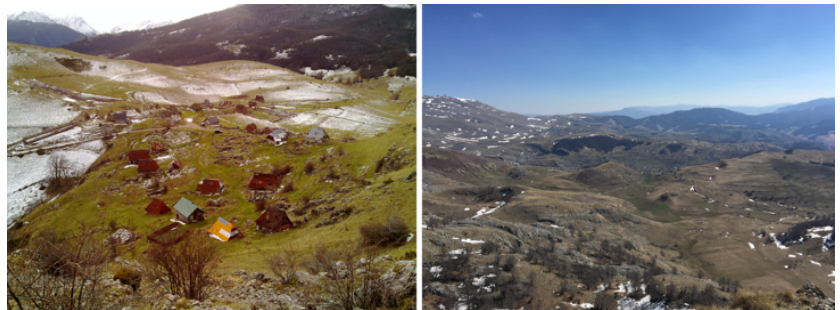

Figure 14: Katun settlement above Umoljani
Beside the katun settlement are extensive meadows and arable land and pastures that continue to Dugi polje and the southern slopes of Bjelasnica.

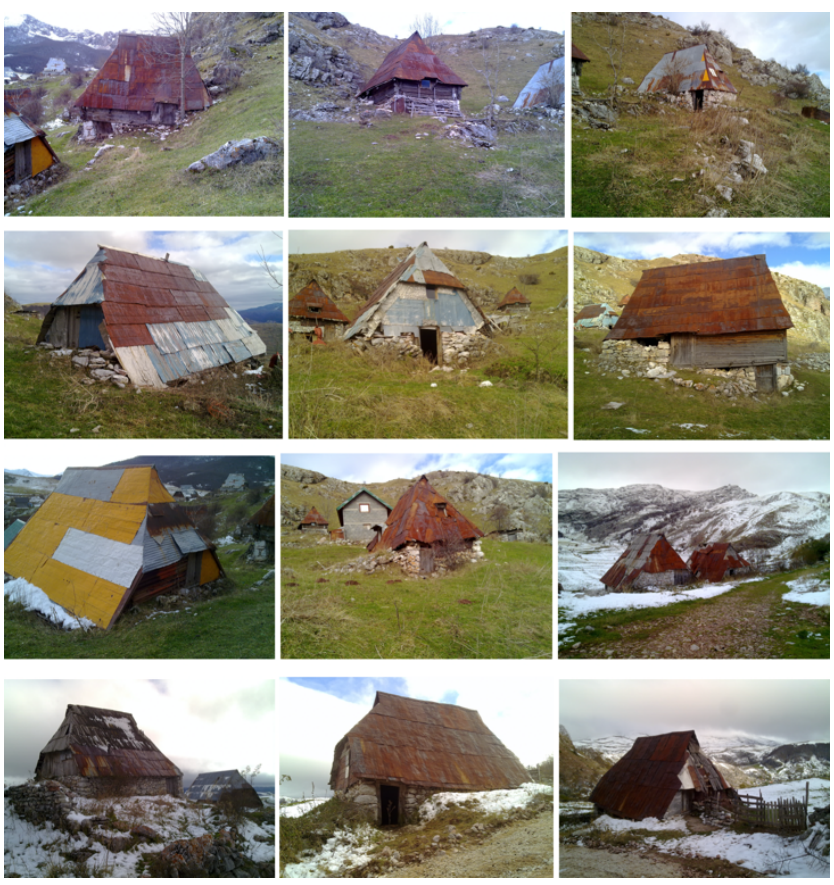

Figure 15: Katun settlement Gradina above Umoljan. Katuns preserved to this day

An extremely important resource is the plateau where the Studeni potok (creek) meanders, which flows into the Rakitnica waterfall at Badnji. This plateau is used as a meadow (on which many types of medicinal bio) grow, (Figure 16, right).

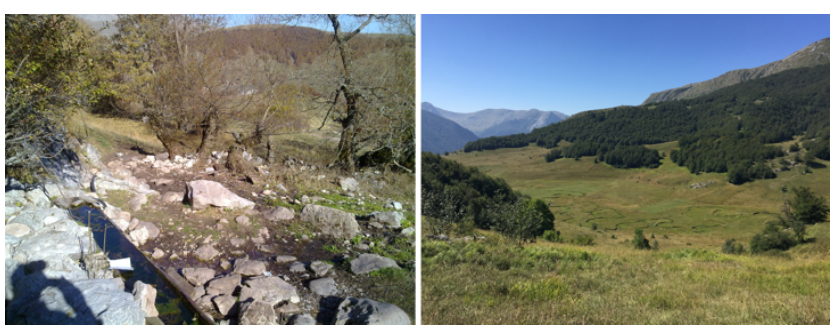

Figure 16: Public fountain with feeder for livestock (left) and Studeni potok (Cold creek) along the katun settlement Gradina

At the foot of the summit of Obalj is a forest from which the inhabitants of Umoljani have traditionally been supplied with firewood and wood for the construction of some structures of buildings.

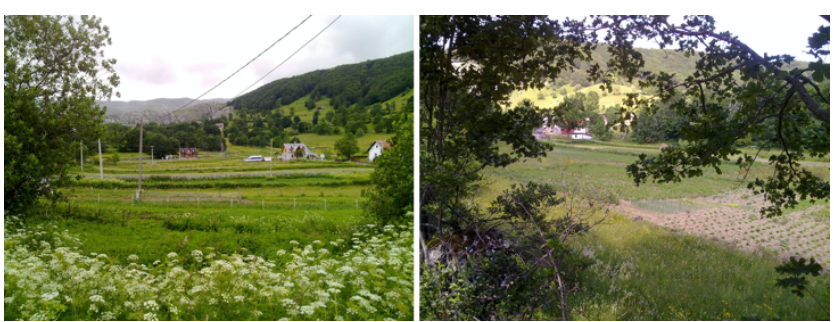

Figure 17: Gardens and meadows near houses in Umoljani 
The Umoljani village was torched during the 1992-1995 war and no examples of traditional architecture were preserved there. We learn about this architecture from old photographs, documentaries and scientific literature.

\section{Perspectives}

The natural environment is more or less a constant of the Umoljani village, while the social environment and man are more flexible categories whose content is changing faster.

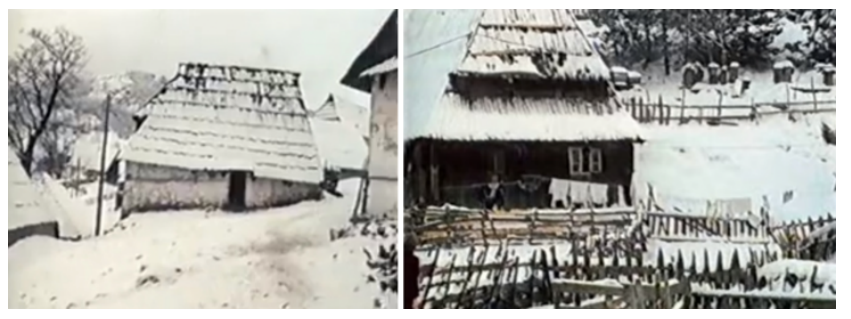

Figure 18: Traditional house in Umoljani. (Source: Documentary film Wedding customs on Bjelasnica (1980s), https://www.facebook.com/BiHFolk/videos/555696468121483/)

The natural and social environment of the Umoljani village will continue to be a prerequisite for living according to its traditional patterns, with a great deal of relief provided by the construction of asphalt roads, dedicated vehicles (for transporting livestock in the winter and summer season, from plateaus to houses in sub-Bjelasnica settlements - Tarčin, Pazarić, Hadžići, Ovčari) and the introduction of modern communication systems (mobile telephony, Internet).

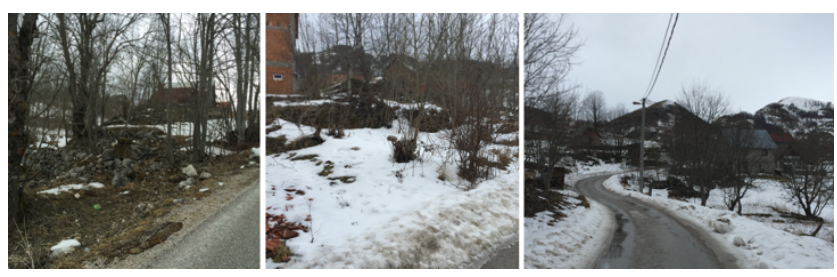

Figure 19: Ruins of traditional structures in Umoljani

The natural and social environment of the Umoljani village is the basis for the whole spectrum of new activities of people: local food restaurants, boarding houses, household arrangements and their rent for the whole season [5].

Mountaineering, visits to the Rakitnica canyon, visits to cultural and historical monuments (pupils and students of all educational levels) are activities that will not bring direct material benefits to the inhabitants of the Umoljani village, but will certainly contribute to its promotion on the international level, which will bring economic benefits.

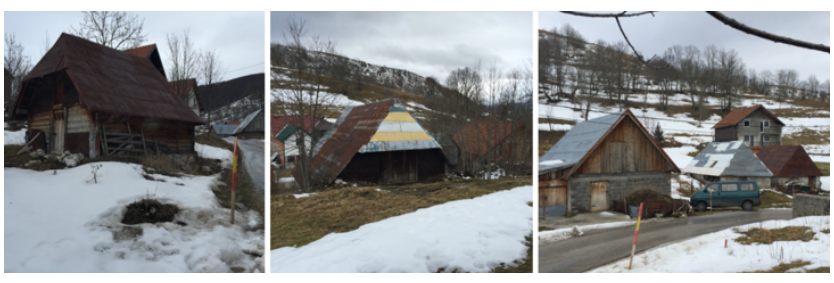

Figure 20: Some newly constructed buildings follow the patterns of traditional architecture
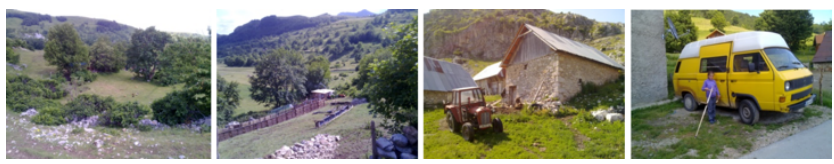

Figure 21: Seasonal living of people in Umoljani

The Umoljani village (as well as the entire of Bjelasnica plateau) will continue to be a valuable resource for the people of Sarajevo, where everyone, according to their needs, will have the space to meet a wide range of needs - appropriate to the people living in the city [6].

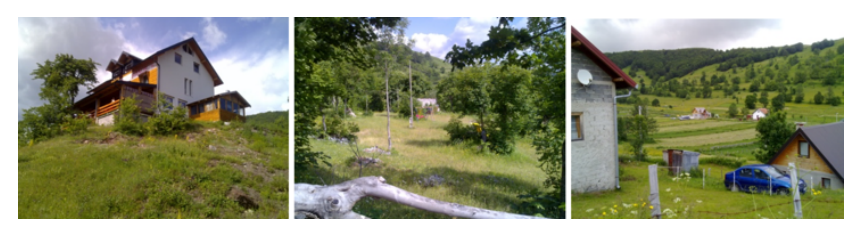

Figure 22: Domestic food restaurants with accommodation „Umoljani" (left and center) and „Studeni potok" (right)

Architecture as a framework of life on the plateau of Bjelasnica will always find its new patterns (Figures 18, 19, 20, 21, 22, and 23) and the language of expression since the future inputs of life are very powerful, and with some good perspectives.
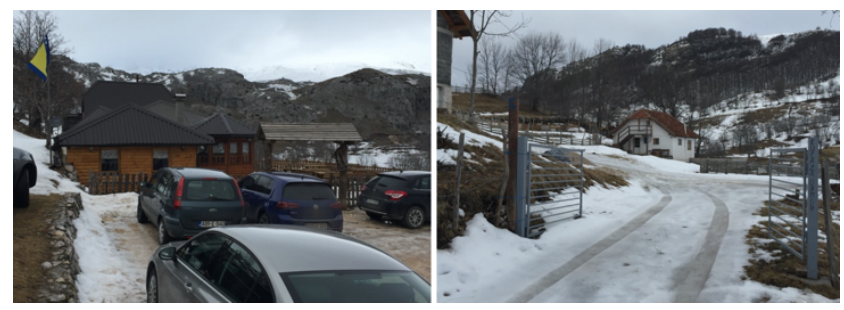

Figure 23: Domestic food restaurant „Koliba“ („Hut") with accommodation (left) and house for rent - "Living in the country" (right)

\section{References}

1. Čelebija E. Putopis. Odlomci o jugoslovenskim zemljama. Sarajevo: SarajevoPublishing; 1996.
2.
Hadrović,
A. (2007.),
Defining 
Architecrural Space on the Model of the Oriental Style City House in Bosnia and Herzegovina, Serbia, Montenegro, Kosovo and Macedonia, Booksurge, LLC, North Charleston, SC, USA

3. Hadrović A. Bioclimatic Architecture, Searching for a Path to Heaven. SC, USA: Booksurge, LLC, North Charleston; 2008.

4. Hadrović A. Water and man in autoshthonous symbiosis in Bosnia and Herzegovina. Sarajevo: Avicena; 2014.

5. Pasch K. Glasnik Zemaljskog muzeja u Sarajevu. Sarajevo; 1902.

6. Popović J. Kroz planine Bosne i Hercegovine. Sarajevo: Izdanje planinarskih društava u Sarajevu; 1935. 